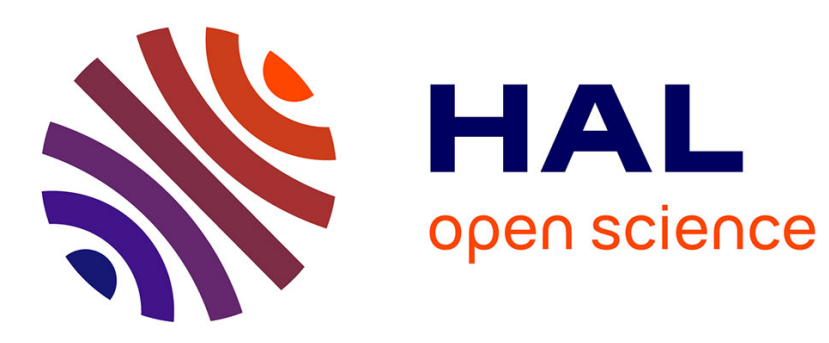

\title{
A spectroscopic NMR investigation of the calcium silicate hydrates present in cement and concrete
}

Hélène Zanni, Racha Rassem-Bertolo, Sylvie Masse, Lorenzo Fernandez, Pedro Nieto, Bruno Bresson

\section{- To cite this version:}

Hélène Zanni, Racha Rassem-Bertolo, Sylvie Masse, Lorenzo Fernandez, Pedro Nieto, et al.. A spectroscopic NMR investigation of the calcium silicate hydrates present in cement and concrete. Magnetic Resonance Imaging, 1996, 14 (7-8), pp.827-831. 10.1016/S0730-725X(96)00211-1 • hal-02318973

\section{HAL Id: hal-02318973 \\ https://hal.sorbonne-universite.fr/hal-02318973}

Submitted on 5 Jun 2021

HAL is a multi-disciplinary open access archive for the deposit and dissemination of scientific research documents, whether they are published or not. The documents may come from teaching and research institutions in France or abroad, or from public or private research centers.
L'archive ouverte pluridisciplinaire HAL, est destinée au dépôt et à la diffusion de documents scientifiques de niveau recherche, publiés ou non, émanant des établissements d'enseignement et de recherche français ou étrangers, des laboratoires publics ou privés. 
archives-ouvertes

\section{A spectroscopic NMR investigation of the calcium silicate hydrates present in cement and concrete}

Hélène Zanni, Racha Rassem-Bertolo, Sylvie Masse, Lorenzo Fernandez, Pedro Nieto, Bruno Bresson

\section{- To cite this version:}

Hélène Zanni, Racha Rassem-Bertolo, Sylvie Masse, Lorenzo Fernandez, Pedro Nieto, et al.. A spectroscopic NMR investigation of the calcium silicate hydrates present in cement and concrete. Magnetic Resonance Imaging, Elsevier, 1996, 14 (7-8), pp.827-831. 10.1016/S0730-725X(96)00211-1 . hal02318973

\section{HAL Id: hal-02318973 \\ https: / hal.sorbonne-universite.fr/hal-02318973}

Submitted on 5 Jun 2021

HAL is a multi-disciplinary open access archive for the deposit and dissemination of scientific research documents, whether they are published or not. The documents may come from teaching and research institutions in France or abroad, or from public or private research centers.
L'archive ouverte pluridisciplinaire HAL, est destinée au dépôt et à la diffusion de documents scientifiques de niveau recherche, publiés ou non, émanant des établissements d'enseignement et de recherche français ou étrangers, des laboratoires publics ou privés. 


\title{
A SPECTROSCOPIC NMR INVESTIGATION OF THE CALCIUM SILICATE HYDRATES PRESENT IN CEMENT AND CONCRETE
}

\author{
Hélène Zanni, Racha Rassem-Bertolo, Sylvie Masse, Lorenzo Fernandez, \\ Pedro NiETo, AND BRuno BRESSON
}

Laboratoire de Physique et de Mécanique des Milieux Hétérogènes, URA CNRS 857, E.S.P.C.I. 10, rue Vauquelin 75231 Paris Cedex 05, France, and Université Pierre et Marie Curie, 4, place Jussieu, 75252 Paris Cedex 05, France

\begin{abstract}
NMR spectroscopy is applied to study microstructure of calcium silicate hydrates present in cement and concrete. It is shown that ${ }^{29} \mathrm{Si}$ NMR gives information on the siliceous skeleton of the hydrates. ${ }^{1} \mathrm{H}$ NMR, using CRAMPS techniques, allows to discriminate between protons linked to silicon atoms or to calcium atoms. A first investigation of reference compounds indicates that ${ }^{43} \mathrm{Ca}$ NMR will be powerful to determine calcium atom sites in the structure.
\end{abstract}

Keywords: NMR spectroscopy; Silicates; Inorganic polymerization; Cement.

\section{INTRODUCTION}

Our goal is to show how NMR spectroscopy gives informations on growth kinetics and microstructure of calcium silicate hydrates that can develop in cement and concrete.

Ordinary Portland cement is composed of clinker mixed with a few percent of gypsum. Clinker contains four basic constituents, bi- and tricalcium silicates, $\mathrm{C}_{2} \mathrm{~S}^{*}$ and $\mathrm{C}_{3} \mathrm{~S} *$. ( ${ }^{*} \mathrm{Cement}$ notation is used: $\mathrm{C}=\mathrm{CaO}$, $\mathrm{S}=\mathrm{SiO}_{2}, \mathrm{~A}=\mathrm{Al}_{2} \mathrm{O}_{3}, \mathrm{~F}=\mathrm{Fe}_{2} \mathrm{O}_{3}, \mathrm{H}=\mathrm{H}_{2} \mathrm{O}$ ), tricalcium aluminate, $\mathrm{C}_{3} \mathrm{~A}$ *, and tetracalcium aluminoferrite, $\mathrm{C}_{4} \mathrm{AF}^{*}$ (typical proportions are $\mathrm{C}_{3} \mathrm{~S}: 50$ to $70 \%$, $\mathrm{C}_{2} \mathrm{~S}: 15$ to $30 \%, \mathrm{C}_{3} \mathrm{~A}: 5$ to $10 \%$ and $\mathrm{C}_{4} \mathrm{AF}$ : 5 to $10 \%$ ). $\mathrm{C}_{3} \mathrm{~S}$ is the major component of cement. So, this work will deal with the silicate phases hydration. The hydration leads to the formation of the so-called $\mathrm{C}-\mathrm{S}-\mathrm{Hs}$ *, which insure cohesion and setting of the material. C$\mathrm{S}-\mathrm{Hs}$ are known to be nonstoechiometric and poorly crystallized (they are "nanocrystalline"); their stoechiometry and, therefore, their structure are strongly dependent on the physico-chemical conditions of elaboration such as temperature, pressure, cement granulometry, water/cement ratio $(\mathrm{w} / \mathrm{c})$ used for hydration, carbonation, adjonction of admixtures. The stoechiometric ratio, $\mathrm{Ca} / \mathrm{Si}$, can be varied in a wide range, from 1.7 (cement paste hydrated in normal conditions of temperature and pressure with a standard ratio $\mathrm{w} / \mathrm{c}$ $=0.5$ ) to 0.66 (ratio of crystalline tobermorite) under specific curing conditions.

In hydration process of cement silicates, three complex (because concomitant) chemical reactions take place: ${ }^{1}$ $\mathrm{C}_{3} \mathrm{~S}$ (and $\mathrm{C}_{2} \mathrm{~S}$ ) dissolution, $\mathrm{C}-\mathrm{S}-\mathrm{H}$ precipitation and $\mathrm{CH}$ precipitation. Portlandite, $\mathrm{CH}$, forms large hexagonal crystals which are embedded in the $\mathrm{C}-\mathrm{S}-\mathrm{H}$ network. The presence of portlandite is not favourable for the development of high mechanical resistances.

Addition of silica fume to the cement formulation is responsible for the pozzolanic reaction. It corresponds to the reaction of silicate ions (issued from silica fume dissolution in water) with calcium ions (issued from the portlandite redissolution) and forms new $\mathrm{C}-\mathrm{S}-\mathrm{H}$ with a different stoechiometry ${ }^{2}$ from that of $\mathrm{C}-\mathrm{S}-\mathrm{H}$ produced by $\mathrm{C}_{3} \mathrm{~S}$ hydration. So, pozzolanic reaction has two effects: the consumption of portlandite and an enhancement of the total amount of $\mathrm{C}-\mathrm{S}-\mathrm{H}$.

Finally, in some concretes composed of reactive siliceous aggregates, silica of the aggregates may pass in solution under the action of alkaline water and react with the cations, $\mathrm{Na}^{+}\left(\right.$or $\left.\mathrm{K}^{+}\right)$, and $\mathrm{Ca}^{2+}$ present in solution. This reaction can produce a swelling gel, $\mathrm{C}-$ $\mathrm{Na}-\mathrm{S}-\mathrm{H}$ ( or $\mathrm{C}-\mathrm{K}-\mathrm{S}-\mathrm{H}$ ) with a similar structure to that of $\mathrm{C}-\mathrm{S}-\mathrm{H}^{3.4}$
Address correspondence to $\mathrm{H}$. Zanni, Laboratoire de Physique et de Mécanique des Milieux Hétérogènes, URA,
CNRS 857, E.S.P.C.I. 10, rue Vauquelin 75231 Paris, Cedex 05, France. 


\section{NMR SPECTROSCOPY}

In calcium silicate hydrates all the constitutive atoms have nuclear isotopes detectable by NMR: silicon ${ }^{29} \mathrm{Si}$, proton ${ }^{1} \mathrm{H}$, calcium ${ }^{43} \mathrm{Ca}$, and oxygen ${ }^{17} \mathrm{O}$ (with enrichment in these two last cases). Consequently, we undertook the observation of ${ }^{29} \mathrm{Si},{ }^{1} \mathrm{H}$, and ${ }^{43}$ Ca nuclei.

In the case of ${ }^{29} \mathrm{Si}$ nuclei ( $\operatorname{spin} \frac{1}{2}$ ), single pulse excitation allows to make a quantitative analysis of the different silicon species coexisting in the sample, the peaks areas being proportional to the amounts of ${ }^{29} \mathrm{Si}$ entities. Using Magic Angle Spinning, only the isotropic chemical shift interaction remains, leading to well-resolved peaks in the spectra, the position of which are characteristic of the different ${ }^{29} \mathrm{Si}$ sites types. The analysis is based on the $Q^{\mathrm{n}}$ classification ${ }^{5}$ where $Q$ represents a $\mathrm{SiO}_{4}^{4-}$ unit and the degree of connectivity, $n$, is related to the oxygen bonds number between the $\mathrm{SiO}_{4}^{4-}$ units. Furthermore, Crosspolarization-MAS experiment can be used to reveal only the silicon nuclei in interaction with protons.

In these systems, protons present very broad spectra because of a strong dipolar interaction and in MAS experiment a very high rotation speed is necessary to resolve the spectra. So we used CRAMPS (Combined Rotation And MultiPulses Spectroscopy) techniques, which have been improved since the first pioneering experiments done by Heidemann ${ }^{6}$ on crystalline calcium silicate hydrates and some first attempts on $\mathrm{C}-\mathrm{S}-\mathrm{H}^{\mathrm{7}}$

In order to observe the ${ }^{43} \mathrm{Ca}$ isotope of calcium (spin $I=7 / 2$, natural abundance $0.145 \%$ ) in reference compounds, a $58 \%$ enrichment of the samples was done.

All NMR experiments were performed on CXP or ASX 300 and ASX 500 BRUKER spectrometers, associated with fields of 7.03 and $11.7 \mathrm{~T}$, respectively. MAS experiments were realized with a spinning speed of $7 \mathrm{kHz}$ and BR24 multipulses sequences were used in CRAMPS experiments.

\section{RESULTS}

A study of $\mathrm{C}_{3} \mathrm{~S}$ hydration has been done, ${ }^{8,9}$ varying temperature $\left(20^{\circ} \mathrm{C}\right.$ to $\left.120^{\circ} \mathrm{C}\right)$ and duration $(5 \mathrm{~min}$ to 1 yr) of hydration. The following features were observed; the acceleration of $\mathrm{C}_{3} \mathrm{~S}$ consumption with increasing temperature and the lenghening of $\mathrm{C}-\mathrm{S}-\mathrm{H}$ skelcton chains. Unlike the hydration at room temperature ${ }^{10}$ the silicate chains are no longer trimer (statistically) but penta- or hexamer. As example, we present on Fig. 1 the spectra of $\mathrm{C}_{3} \mathrm{~S}$ samples hydrated at $120^{\circ} \mathrm{C}$ during various times. The anhydrous $\mathrm{C}_{3} \mathrm{~S}$ is revealed by a peak in the $Q^{0}$ range in the $30 \mathrm{mn}$ and $3 \mathrm{~h}$ spectra. The $\mathrm{C}-\mathrm{S}-\mathrm{H}$ spectra are composed of $Q^{1}$ peaks (end-chains tetrahedra) and $Q^{2}$ peaks (middle chains tetrahedra).
On Fig. 2, the CP-MAS spectrum of a sample hydrated at $120^{\circ} \mathrm{C}$ during 7 days reveals two nonequivalent $Q^{2}$ sites in the chains, located at -82.7 and -85.4 $\mathrm{ppm}$. The $-82.7 \mathrm{ppm}$ peak is attributed to "bridging tetrahedra," which link pairs of $\mathrm{SiO}_{4}$ dimers like in tobermorite structure. This peak appears for decreasing $\mathrm{Ca} / \mathrm{Si}$ ratio. But it has been shown ${ }^{11}$ that the stoechiometric ratio was totally dependent on the calcium and silicates ions concentrations in the mother solutions, before $\mathrm{C}-\mathrm{S}-\mathrm{H}$ precipitation. Thus, these concentrations are the key parameters controlling the $\mathrm{C}-\mathrm{S}-\mathrm{H}$ structure. Other parameters, like temperature or carbonation or silica fume addition, which are able to modify the ionic concentrations in solution and so influence the $\mathrm{Ca} / \mathrm{Si}$ ratio and the length of the chains, appear to be "secondary" parameters. For a ratio smaller than 0.66 , chains can link and form more polymerized silicates. This phenomenon has been observed ${ }^{3.4}$ in a study simulating alkali-aggregate reaction.

To simulate this reaction, silica alkaline solutions with various silica and alkali concentrations were pre-

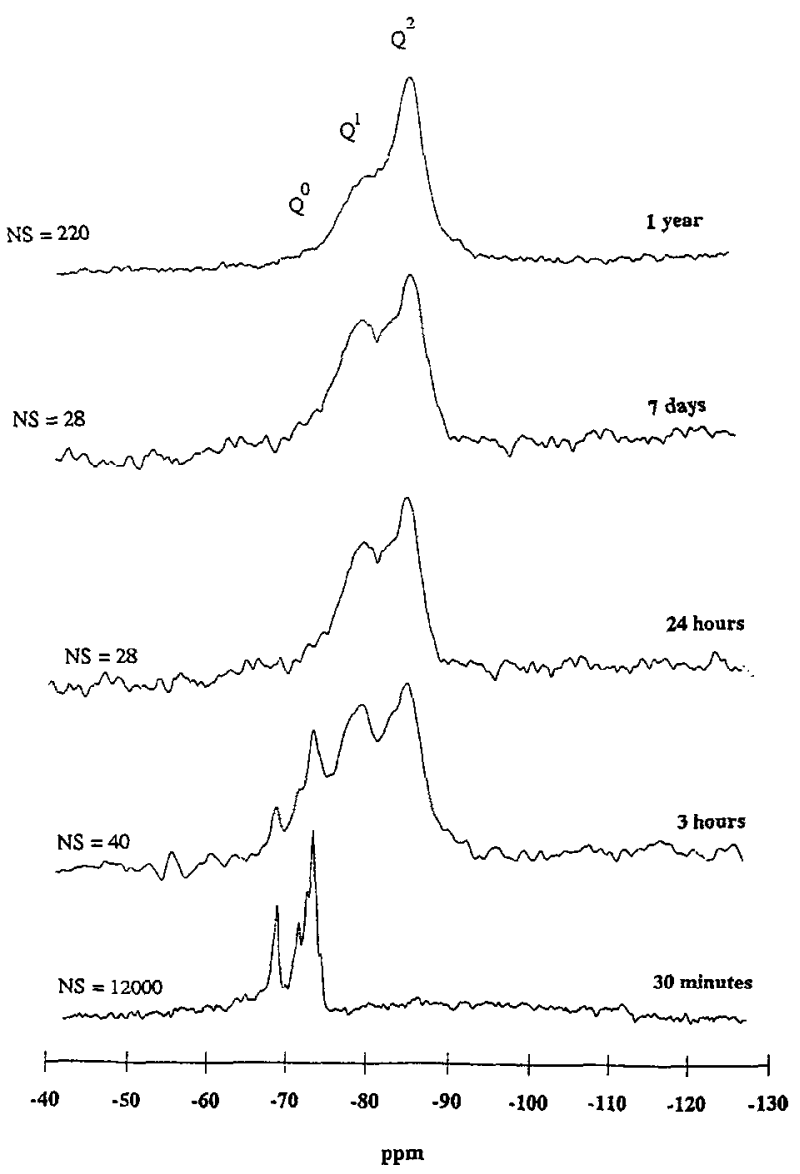

Fig. 1. ${ }^{29} \mathrm{Si}$ NMR spectra of $\mathrm{C}_{3} \mathrm{~S}$ hydrated at $120^{\circ} \mathrm{C}$ during various times. MAS SPE experiments. Chemical shift values are calibrated using $\mathrm{Q}_{8} \mathrm{M}_{8}\left[\mathrm{Si}\left(\mathrm{CH}_{3}\right)_{3}\right]_{8} \mathrm{Si}_{8} \mathrm{O}_{20}$ relatively to TMS, the tetramethylsilane $\mathrm{Si}\left(\mathrm{CH}_{3}\right)_{4}$. 


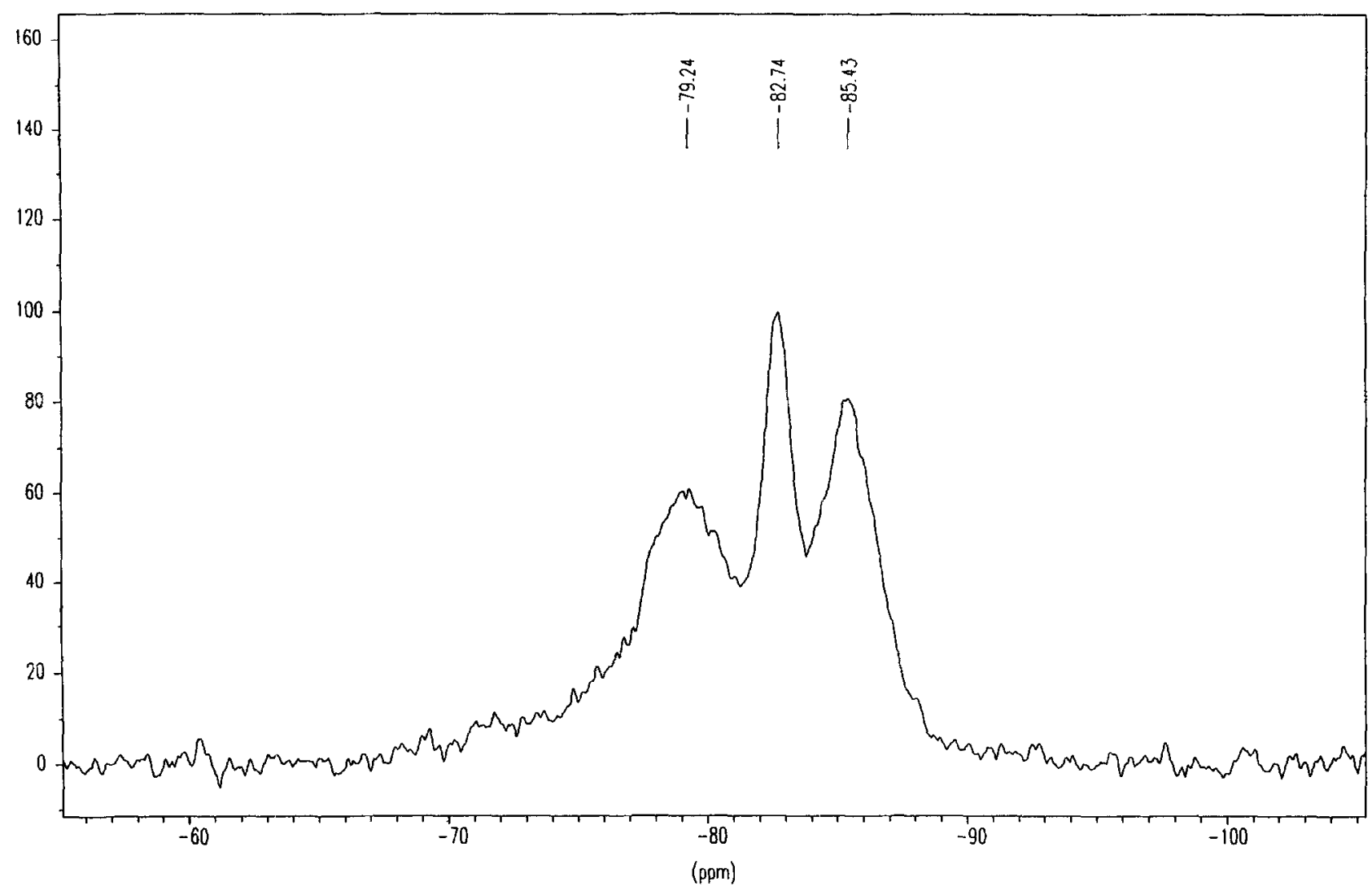

Fig. 2. ${ }^{29} \mathrm{Si}$ NMR spectrum of $\mathrm{C}_{3} \mathrm{~S}$ hydrated at $120^{\circ} \mathrm{C}$ during 7 days. CP-MAS experiment showing the two $\mathrm{Q}^{2}$ sites in the $\mathrm{C}-\mathrm{S}-\mathrm{H}$ structure.

pared. These solutions are characterized by their molar ratio $\mathrm{Rm}, \mathrm{SiO}_{2} / \mathrm{Na}_{2} \mathrm{O}$ (or $\mathrm{SiO}_{2} / \mathrm{K}_{2} \mathrm{O}$ ). An NMR study of the solutions has shown the presence of ionic precursors whose sizes are totally dependent on the $\mathrm{Rm}$ ratio. Adding calcium compounds $\left(\mathrm{CaCl}_{2}, \mathrm{CaSO}_{4}\right.$ or $\left.\mathrm{Ca}(\mathrm{OH})_{2}\right)$ to these solutions leads to the precipitation or coagulation of solid phases. Their spectra are presented on Fig. 3 which shows that all possible silicate structures are obtained. At low $\mathrm{Rm}$ ratios, the structure of the precipitates are similar to that of cement $\mathrm{C}-\mathrm{S}$ $\mathrm{H}$, based on tetrahedra chains. For higher Rm ratios, structures based on $Q^{2}$ and $Q^{3}$ entities appear first, then, silica gel structures based on $Q^{3}$ and $Q^{4}$ entities, for very large concentration of silica. Comparing these spectra to the spectrum of the "real" alkali-aggregate reaction product, it may be concluded that its structure is based on $Q^{2}$ and $Q^{3}$ entities.

It is obvious that ${ }^{29} \mathrm{Si} \mathrm{NMR}$ gives the siliceous skeleton of silicate hydrates and very few informations on location of protons in the $\mathrm{C}-\mathrm{S}-\mathrm{H}$ structure. $\mathrm{CP}-\mathrm{MAS}$ experiments can reveal only the presence of protons in the vicinity of the silicon nuclei. So CRAMPS techniques were applied to resolve the very broad proton spectrum of $\mathrm{C}-\mathrm{S}-\mathrm{H}$. As first results, we present, on Fig. 4, the spectra of $\mathrm{C}_{3} \mathrm{~S}$ samples hydrated at $120^{\circ} \mathrm{C}$ during different times. On each spectrum two peaks are observed: one located at $5.5 \mathrm{ppm}$, and the other at $0.5 \mathrm{ppm}$. Considering Heidemann's classification, the first peak can be attributed to $\mathrm{Si}-\mathrm{OH}$ and $\mathrm{H}-\mathrm{OH}$ protons and the second one to $\mathrm{Ca}-\mathrm{OH}$ protons. Both $\mathrm{C}-$ $\mathrm{S}-\mathrm{H}$ and $\mathrm{CH}$ protons contribute to this second peak but its enhancement with increasing hydration time clearly reveals porlandite growth in the medium.

Preliminary results concerning ${ }^{43} \mathrm{Ca}$ NMR are presented on Fig. 5. The spectra correspond to some references of importance in the field of cement and concrete: $\mathrm{CaCO}_{3}, \mathrm{CaO}$, or $\mathrm{Ca}(\mathrm{OH})_{2}$. All the compounds are characterized by distinguishable ${ }^{43} \mathrm{Ca}$ NMR spectra. So, we hope to be able to detect, if they exist, different calcium atom sites in the $\mathrm{C}-\mathrm{S}-\mathrm{H}$ structure by ${ }^{13} \mathrm{Ca} \mathrm{NMR}$.

\section{CONCLUSION}

In conclusion, we wish to emphasize that the structure of the calcium silicate hydrates is strongly dependent on the initial ionic concentrations of the mother solutions from which they are issued: $\mathrm{SiO}^{4-}$ and $\mathrm{Ca}^{2+}$ concentrations in the case of $\mathrm{C}-\mathrm{S}-\mathrm{H}$ resulting from cement hydration and pozzolanic reaction, $\mathrm{SiO}^{4-}$ and alkaline concentrations in the case of alkali-aggregates 


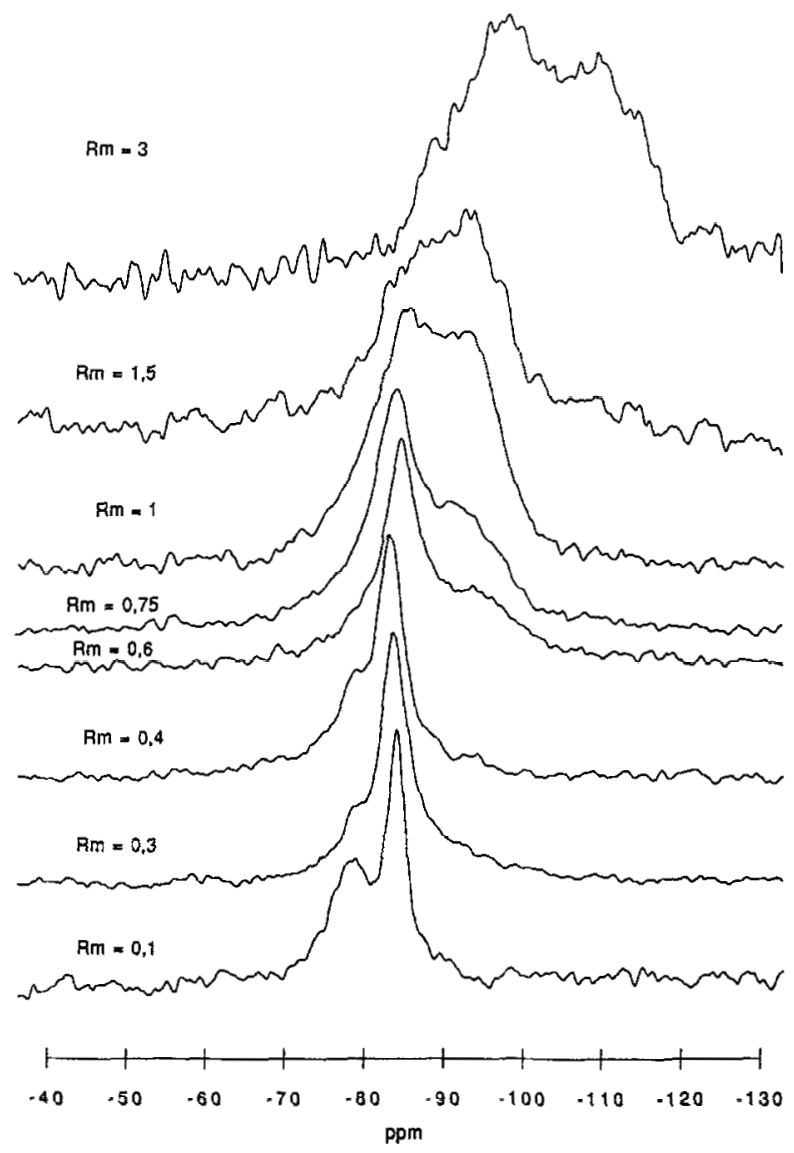

Fig. 3. ${ }^{29} \mathrm{Si}$ NMR spectra of solid $\mathrm{C}-\mathrm{Na}-\mathrm{S}-\mathrm{H}$ obtained by action of calcium compound on silica alkaline solutions. MAS SPE experiments.

reaction gel. All the parameters modifying the concentrations lead to changes in the stoechiometry, structure, and mechanical properties of the solid phases.

Acknowledgments - We are very grateful to M.F. Quinton for her precious help in CRAMPS experiments.

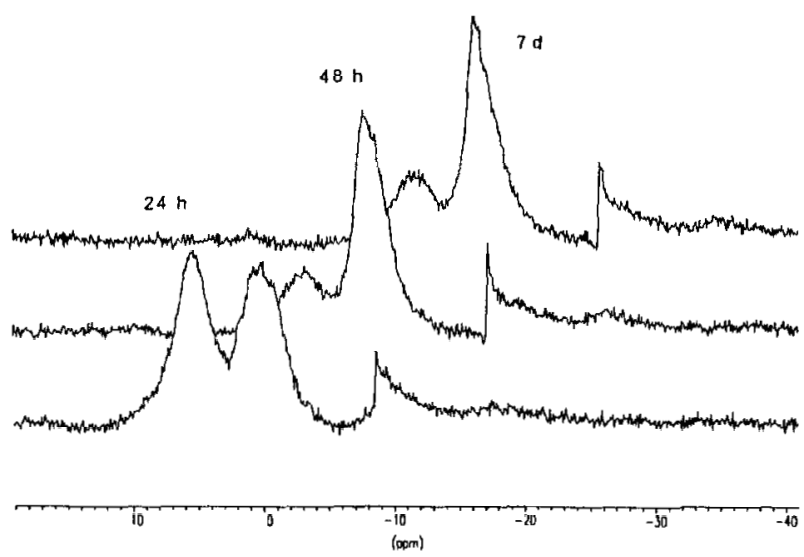

Fig. 4. ${ }^{1} \mathrm{H}$ CRAMPS spectra of $\mathrm{C}_{3}$ S hydrated at $120^{\circ} \mathrm{C}$ during various times showing the portlandite growth during the time.

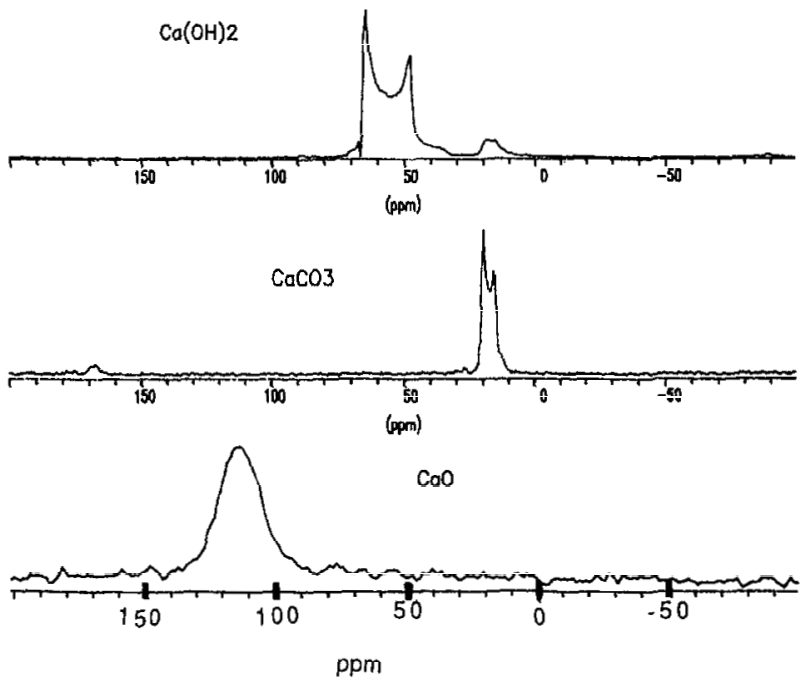

Fig. 5. ${ }^{43} \mathrm{Ca}$ NMR spectra of typical calcium compounds: $\mathrm{CaO}, \mathrm{CaCO}_{3}, \mathrm{CA}(\mathrm{OH})_{2} \cdot{ }^{43} \mathrm{Ca}$ enrichment of the samples: $58 \%$.

\section{REFERENCES}

1. Barret, P.; Bertrandie, D. Fundamental hydration kinetic features of the major cement constituents: Tricalcium silicate $\mathrm{Ca}_{3} \mathrm{SiO}_{5}$ and beta-calcium silicate $\mathrm{Ca}_{2} \mathrm{SiO}_{4}$. J. Chim. Phys. 83:765-775; 1986.

2. Brough, A.R.; Dobson, C.M.; Richardson, I.G.; Groves, G.M. A study of the pozzolanic rcaction by solid-state ${ }^{29} \mathrm{Si}$ NMR using selective isotopic enrichment. J. Mater. Sci., 30:1671-1678; 1995.

3. Fernandez, L.; Zanni, H.; Couty, R.; Barret, P.; Bertrandie, D. Contribution of ${ }^{29} \mathrm{Si}$ high-resolution NMR to the study of concrete alkali-aggregates reaction. J. Chim. Phys. 89:453-460; 1992.

4. Zanni, H.; Nieto, P.; Fernandez, R.; Couty, R.; Barret, P.; Nonat, A.; Bertrandie, D. Sol-gel transition in silica alkaline solutions. An NMR study. J, Chim. Phys. 91:901-908; 1994.

5. Engelhard, G.; Michel, D. High resolution ${ }^{29} \mathrm{Si}$ NMR of silicates and zeulites. Chichester: John Wiley; 1987.

6. Heidemann, D. Proton high-resolution solid-state NMR spectroscopy using CRAMPS techniques for studies in silicates and cement science, in "Applications of NMR spectroscopy to cement science", $P$. Colombet; A.R. Grimmer (Eds). Amsterdam: Gordon and Breach; 1994: pp. 77-102.

7. Rassem, R.; Zanni, H.; Heidemann, D.; Grimmer, A.R. Proton high resolution solid state NMR studies of C.3S hydration. Cem. Concr. Res. 23:169-176; 1993.

8. Masse, S.; Zanni, H.; Lecourtier, J.; Roussel, J.C.; Rivereau, A. ${ }^{29} \mathrm{Si}$ solid state NMR study of tricalcium silicate and cement hydration at high temperature. Cem. Concr. Res. 23:1169-1177; 1993.

9. Masse, S.; Zanni, H.; Lecourtier, J.; Roussel, J.C.; Rivereau, A. High temperature hydration of tricalcium 
silicate, the major component of Portland cement: A silicon-29 NMR contribution. J. Chim. Phys. 92: 1861-1866; 1995.

10. Rassem, R.; Zanni-Theveneau, H.; Schneid, I.; Regourd, M. ${ }^{29}$ Si high resolution NMR study of trical- cium silicate hydration. J. Chim. Phys. 86:12531264; 1989.

11. Nonat, A. Interactions between chemical evolution (hydration) and physical evolution (setting) in the case of tricalcium silicate. Mater. Struct. 27:187-195; 1994. 